\title{
Antioxidant Effects of Statins in the Management of Cardiometabolic Disorders
}

\author{
Soo Lim ${ }^{1}$ and Philip Barter ${ }^{2}$
}

${ }^{1}$ Department of Internal Medicine, Seoul National University Bundang Hospital, Seoul National University College of Medicine, Seongnam, Korea

${ }^{2}$ Centre for Vascular Research, University of New South Wales, Sydney, Australia

Redox systems are key players in vascular health. A shift in redox homeostasis-that results in an imbalance between reactive oxygen species (ROS) generation and endogenous antioxidant defenses has the potential to create a state of oxidative stress that subsequently plays a role in the pathogenesis of a number of diseases, including those of the cardiovascular and metabolic system. Statins, which are primarily used to reduce the concentration of low-density lipoprotein cholesterol, have also been shown to reduce oxidative stress by modulating redox systems.

Studies conducted both in vitro and in vivo support the role of oxidative stress in the development of atherosclerosis and cardiovascular diseases. Oxidative stress may also be responsible for various diabetic complications and the development of fatty liver. Statins reduce oxidative stress by blocking the generation of $\mathrm{ROS}$ and reducing the $\mathrm{NAD}+/ \mathrm{NADH}$ ratio. These drugs also have effects on nitric oxide synthase, lipid peroxidation and the adiponectin levels.

It is possible that the antioxidant properties of statins contribute to their protective cardiovascular effects, independent of the lipid-lowering actions of these agents. However, possible adverse effects of statins on glucose homeostasis may be related to the redox system. Therefore, studies investigating the modulation of redox signaling by statins are warranted.

J Atheroscler Thromb, 2014; 21:997-1010.

Key words: Redox, Statin, Antioxidant, Reactive oxygen species, Cardiometabolic disorders

\begin{abstract}
Abbreviations; HMG-CoA: 3-hydroxy-3-methylglutaryl CoA, ROS: Reactive oxygen species, LDL: Low-density lipoprotein, TNF $\alpha$ : Tumor necrosis factor- $\alpha$, IL6: Interleukin-6, PPAR $\gamma$ : Peroxisome proliferators-activated receptors- $\gamma$, SOD1: Superoxide dismutase 1, VLCFAs and LCFAs: Very long and long chain fatty acids, NAFLD: Non-alcoholic fatty liver disease, NASH: Non-alcoholic steatohepatitis, IL8: Interleukin-8, TGF $\beta$ : Transforming growth factor- $\beta$, PKC: Protein kinase $\mathrm{C}, \mathrm{NAD}+$ : Nicotine adenine dinucleotide, DMSO: Dimethyl sulfoxide, NO: Nitric oxide, AT1: Angiotensin II type I, NOS: Nitric oxide synthase, CAD: Coronary artery disease, HDL: High-density lipoprotein, RAAS: Renin-angiotensin-aldosterone system, Ang II: Angiotensin II, QUICKI: Quantitative Insulin-Sensitivity Check Index
\end{abstract}

\section{Introduction}

Statins, 3-hydroxy-3-methylglutaryl coenzyme A

Address for correspondence: Soo Lim, Internal Medicine, Seoul National University College of Medicine and Seoul National University Bundang Hospital, 300 Gumi-dong, Bundang-gu, Seongnam-city, South Korea

E-mail: limsoo@snu.ac.kr

Received: February 12, 2014

Accepted for publication: June 25, 2014
(HMG-CoA) reductase inhibitors, are widely prescribed in clinical practice to reduce the plasma levels of low-density lipoprotein (LDL) cholesterol. Currently, more than 25 million individuals worldwide take statins ${ }^{1)}$. Treatment with statins has been shown to reduce cardiovascular morbidity and mortality in many landmark clinical trials ${ }^{2,3)}$, and a number of studies suggest that statins have beneficial effects on the cardiovascular system beyond lowering LDL-cholesterol ${ }^{4-7)}$. The 2013 American Heart Association/ 


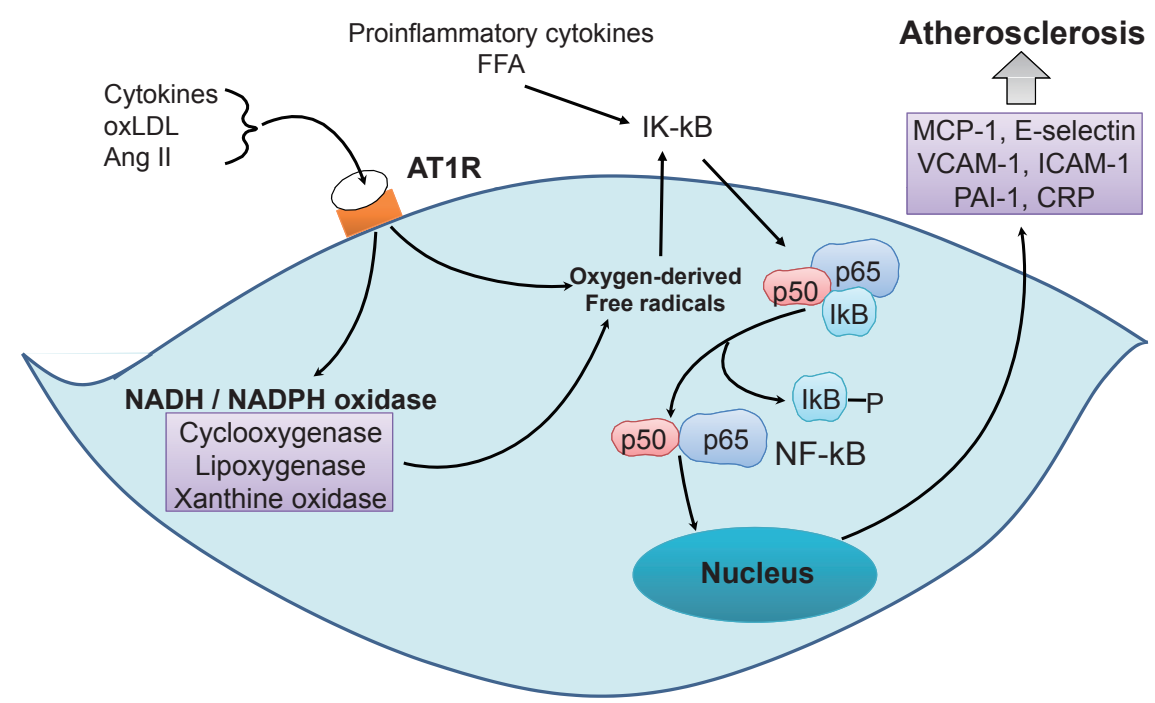

Fig. 1. Schematic representation of the interplay between the redox system, inflammatory processes and development of atherosclerosis in vascular cells

Oxygen-derived free radicals are generated by the binding of angiotensin II (Ang II) to angiotensin II type I receptor (AT1R). Oxygen-derived free radicals dissociate inhibitory factor, IB and thus activate NF- $\kappa$ B. Activated NF- $\kappa$ B then stimulates the expression of proinflammatory genes in the nucleus and production of various proinflammatory chemokines and cytokines, all of which contribute to the development of atherosclerosis.

American College of Cardiology guidelines recommend the administration of high-intensity statin therapy and extend its use to individuals at risk of vascular disease $^{8)}$. One possible effect of statins is their ability to reduce reactive oxygen species (ROS) production and/or activity, which has the potential to inhibit the development of atherosclerosis, independent of LDL reduction ${ }^{9,10)}$. In addition, several studies have demonstrated the antioxidative properties of statins ${ }^{6,11)}$, and it has previously been shown, both in vitro and in vivo, that statins inhibit lipid and lipoprotein oxidation, thereby suppressing ROS formation and/or blunting the damaging effects of these radicals ${ }^{6,12)}$.

The oxidative modification of LDL particles in the vessel wall plays a critical role in the development of atherosclerosis ${ }^{13}{ }^{14}$ ). Therefore, reducing oxidized LDL is a potentially effective method for mitigating the atherogenicity of LDL particles. The observed anti-inflammatory effects of statins also appear to be related to the ability of these drugs to block the production and/or activity of ROS and suppress the oxidation of LDL particles ${ }^{15}$.

In this review, we discuss the effects of statins on redox state regulation from a cardiometabolic perspective, focusing on the antioxidant and anti-inflammatory properties of these agents. The pleiotropic effects of statins have the potential to aid the clinical efficacy of these drugs in treating cardiovascular disorders as well as other chronic conditions associated with oxidative stress. The possible adverse effects of statins on glucose homeostasis, which may be related to the redox system, are also discussed.

\section{Role of the Redox System in the Genesis of Metabolic and Cardiovascular Disorders}

Redox signaling is an important process in a variety of cellular activities, such as cell proliferation, migration, differentiation and apoptosis ${ }^{16-18)}$. Redox injury, as a pathological mechanism, is involved in a wide range of pathophysiological processes, including senescence, inflammation, hypoxia and ischemial reperfusion ${ }^{19,20)}$, all of which may contribute to the progression of various diseases, from cardiovascular disorders, such as hypertension ${ }^{21)}$ and atherosclero$\operatorname{sis}^{22)}$, to metabolic conditions, such as fatty liver ${ }^{23)}$ and type 2 diabetes mellitus (T2DM) ${ }^{24)}$. A schematic representation of the interplay between the redox system, inflammatory processes and development of atherosclerosis is provided in Fig. 1.

\section{Cardiovascular Disease}

\section{Lipid Oxidation and Oxidized LDL}

LDL oxidation is a key player in the initiation 
and progression of atherosclerosis ${ }^{14)}$. LDL is oxidized by ROS released from circulating and vascular wall cells $^{25,26}$. Biochemically, LDL oxidation is the consequence of free radical driven chain reactions in which polyunsaturated fatty acids are converted to lipid peroxides that subsequently generate a range of biologically active aldehydes ${ }^{27)}$.

Oxidatively modified LDL, or oxidized LDL, is involved in the early development of atherosclerotic lesions ${ }^{14)}$. Several in vitro studies have shown that lipid-laden foam cells are formed after macrophages take up oxidized $\mathrm{LDL}^{10,28,29)}$. In addition, the presence of lipid-laden foam cells is a typical feature of vulnerable atherosclerotic lesions. Therefore, the oxidative modification of LDL plays a role in the development of atherosclerotic lesions via the formation of foam cells ${ }^{13)}$. Recent evidence indicates that modified apolipoprotein B derived from oxidized LDL accumulates in foam cells ${ }^{29)}$. Furthermore, macrophagederived foam cells contain many lipid droplets in the cytoplasm, and the levels of oxidized LDL are increased in patients with a history of acute myocardial infarction and carotid artery atherosclerosis ${ }^{28,} 30-32$. Although the role of oxidized LDL in vivo is not completely understood, it has been suggested that measuring the level of oxidized LDL in the plasma may be helpful for predicting the incidence of cardiovascular events $^{28,30}$. Moreover, the presence of oxidized LDL in the LDL fraction of human plasma has been demonstrated using ELISA assays ${ }^{30,32)}$. The accumulation of oxidized LDL in atherosclerotic lesions has also been documented based on the findings of immunohistochemical staining using monoclonal antibodies ${ }^{33)}$.

\section{Relationship between Inflammation and Oxidative Stress in the Setting of CVD}

Inflammation is a complex process that impacts the onset and progression of atherosclerosis and CVD in many different ways ${ }^{34,35)}$. Inflammatory markers shown to be elevated in patients with CVD include the levels of C-reactive protein, interleukin-8 (IL8), monocyte chemoattractant protein-1 (MCP1) and tumor necrosis factor- $\alpha(\mathrm{TNF} \alpha)$, all of which play a crucial role in recruiting neutrophils, $\mathrm{T}$ lymphocytes and monocytes to the vascular wall ${ }^{36,37)}$. In addition, increased CD40-CD40 ligand interactions result in a prothrombotic state ${ }^{38)}$, while increased matrix metalloproteinases lead to plaque rupture ${ }^{39)}$.

Many inflammatory processes are involved in the production and actions of ROS by $\mathrm{NAD}(\mathrm{P}) \mathrm{H}$ oxidase in the vascular wall cell ${ }^{9}$. For example, nuclear factor $(\mathrm{NF})-\kappa \mathrm{B}$, a transcription factor that plays a key role in the expression of proinflammatory cytokines, is posi- tively regulated by $\mathrm{ROS}^{40}$. Consistent with this observation, dimethyl sulfoxide (DMSO), a scavenger of ROS, inhibits the release of proinflammatory cytokines $^{41)}$, whereas ROS contribute to the formation of oxidized LDL, which in turns leads to the deposition of foam cells in atherosclerotic plaques ${ }^{10}$. Therefore, oxidative stress and inflammation are important causative factors for atherosclerotic vascular diseases, particularly under conditions of diabetes ${ }^{42)}$.

\section{Diabetes Mellitus and its Complications}

Oxidative stress associated with lipotoxicity has been known to contribute to the development of T2DM. Mitochondrial dysfunction and lipid homeostasis disruption may also play a role in the onset of insulin resistance ${ }^{43)}$, while functional impairments in mitochondria induce adipocyte dysfunction with a subsequent increase in the circulating levels of free fatty acids (FFAs) and their abnormal deposition in pancreatic $\beta$-cells, thus resulting in lipotoxicity and mitochondrial and pancreatic $\beta$-cell dysfunction ${ }^{44,45)}$.

Several mechanisms have been proposed for the development of diabetic complications (Fig.2), including: (1) an increase in the activity of the polyol pathway, (2) an increase in the activity of the hexosamine pathway, (3) an increase in the formation of advanced glycation end-products, (4) activation of the protein kinase $\mathrm{C}$ (PKC) pathway and (5) an increase in the activity of proinflammatory pathways ${ }^{46-49)}$. Of note, the overactivation of these pathways is caused by the hyperglycemia-induced overproduction of superoxide anions by the mitochondrial electron transport chain. Since the activity of glyceraldehyde phosphate dehydrogenase (GAPDH), a key glycolytic enzyme, is downregulated by superoxide anions, a reduction in the speed of glycolysis leads to an increase in ROS production, thus augmenting a vicious negative feedback cycle ${ }^{50)}$.

In this context, an imbalance of nicotine adenine dinucleotide $(\mathrm{NAD}+)$ and $\mathrm{NADH}$, its reduced form, is a key contributor to target organ damage in patients with diabetes mellitus. NAD + is a coenzyme found in all living cells. NADH is abundant in the cytosol and is an important reducing agent in many enzymatic reactions ${ }^{51,52)}$. NAD $+/ \mathrm{NADH}$ is transported by carriers such as the malate-aspartate shuttle ${ }^{53)}$. The balance between $\mathrm{NAD}+$ and $\mathrm{NADH}$ is important for the regulation of the redox system in cells ${ }^{54)}$, and $\mathrm{NADP}+/ \mathrm{NADPH}$ regulates the activities of enzymes involved in the sirtuin 1, pyruvate dehydrogenase and GAPDH pathways, all of which play a role in the onset of diabetes and its complications ${ }^{45,54-56)}$. Therefore, an imbalance in the redox system contributes to 


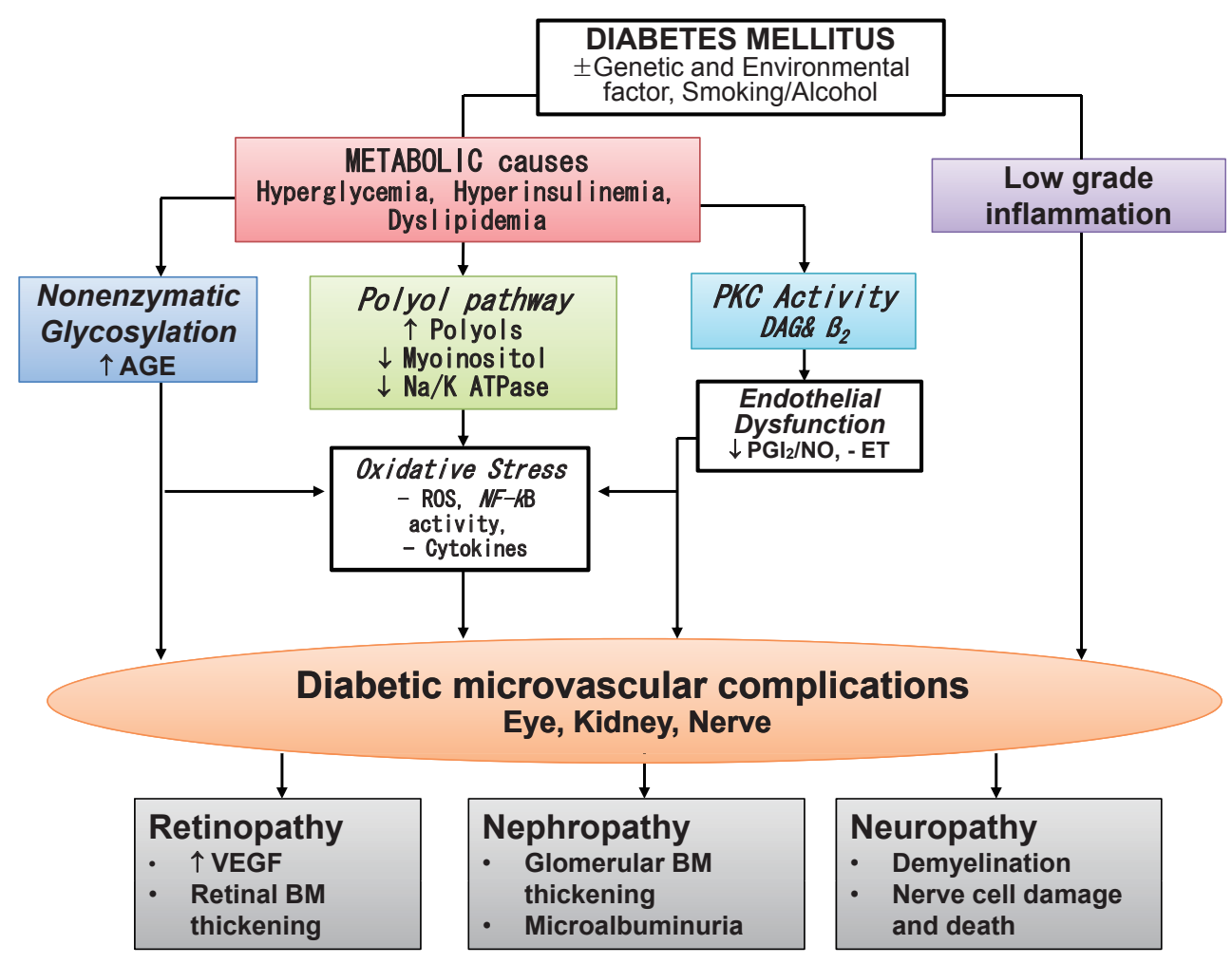

Fig. 2. Theoretic framework for the pathogenesis of diabetic microvascular complications

AGE, advanced glycation end-product; ROS, reactive oxygen species; ET, endothelin; NO, nitric oxide; PKC, protein kinase C; BM, basement membrane; NF-kB, nuclear factor- $\kappa \mathrm{B}$; DAG, diacylglycerol; PGI 2, prostaglandin I2.

the development of diabetes mellitus and its complications.

\section{Obesity and Metabolic Syndrome: Relationships between Insulin Resistance, Oxidative Stress and Inflammation Leading to CVD}

Systemic oxidative stress is associated with abdominal obesity and insulin resistance ${ }^{57,58)}$. Along with oxidative stress, chronic low-intensity inflammation is clinically evident in obese ${ }^{59)}$ and insulin-resistant subjects ${ }^{60)}$, manifesting as increased levels of inflammatory biomarkers, such as C-reactive protein, TNF $\alpha$, IL6 and fibrinogen.

Metabolic syndrome, defined as the clustering of obesity, dyslipidemia, hypertension and insulin resistance $^{61)}$, is a well-known risk factor for the development of T2DM and CVD. Patients with metabolic syndrome frequently have a lipid profile characterized by high triglyceride and low HDL-cholesterol levels with an LDL fraction that is usually not increased in concentration but which consists of small, dense particles that are more susceptible to oxidation. This pattern is highly atherogenic ${ }^{62)}$. According to the Coro- nary Artery Risk Development in Young Adults study, a high concentration of oxidized LDL is associated with an increased incidence of abdominal obesity, hyperglycemia, hypertriglyceridemia and metabolic syndrome ${ }^{63)}$. In a study investigating the association between insulin resistance and lipid peroxidation, patients with metabolic syndrome and/or T2DM were found to have increased levels of oxidation products of linoleic acid and malondialdehyde ${ }^{64)}$. Oxidized LDL activates smooth muscle cells and macrophages to produce gelatinase, which leads to the development of vulnerable plaques ${ }^{65)}$. In an experimental study, preadipocytes exposed to oxidized LDL displayed a high rate of proliferation, low level of apoptosis and increased pre-adipocyte factor- 1 mRNA expression ${ }^{66)}$. These findings suggest that oxidized LDL is a modulator of adipose tissue differentiation and provides a possible link between obesity and its clinical complications.

An increased level of oxidized LDL may be due in part to an impaired HDL-associated antioxidant defense. HDL is known to prevent the formation of oxidized LDL by eliminating seeding molecules from 


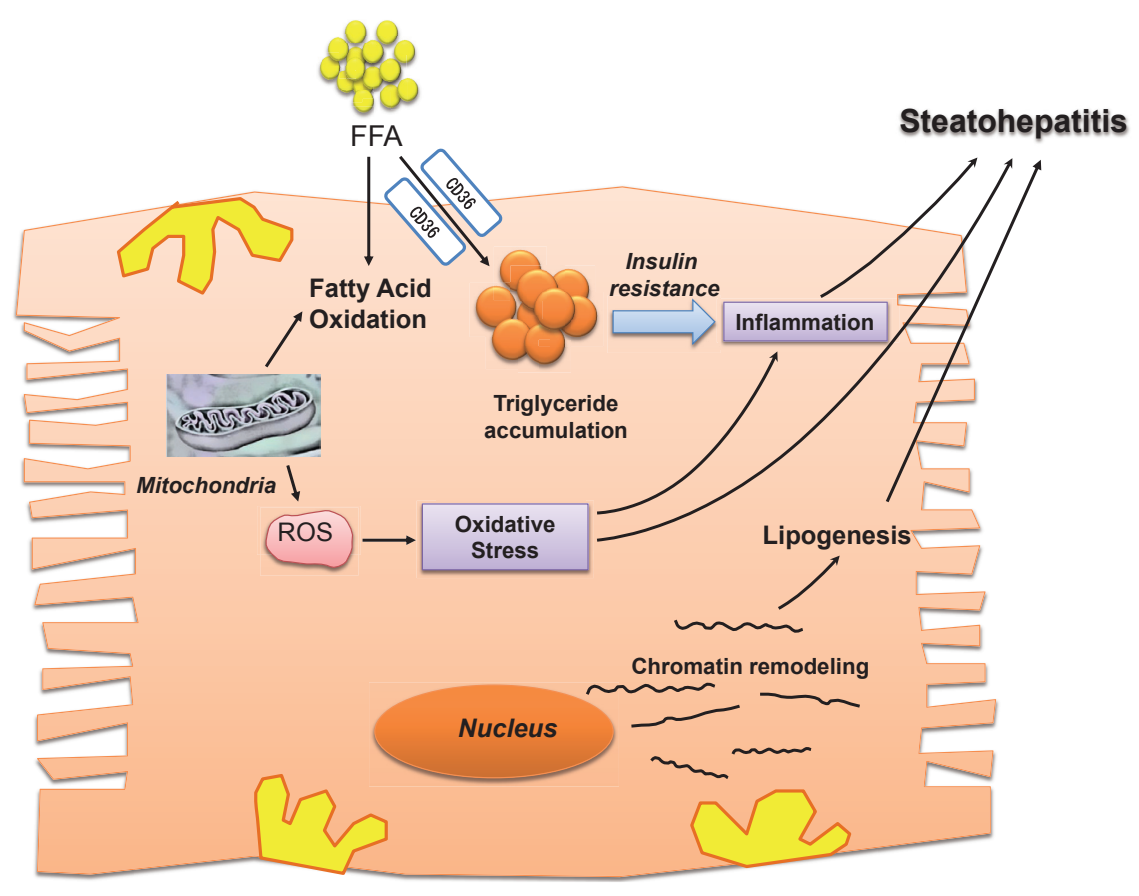

Fig. 3. Role of oxidative stress in the pathogenesis of steatohepatitis. FFA, free fatty acid; ROS, reactive oxygen species.

LDL ${ }^{67)}$. The paraoxonase-1 (PON1) activity associated with HDL has the ability to protect LDL against oxidative modification, and a low level of PON1 is a predictive factor of multivessel involvement of the coronary arteries in patients with hyperglycemia ${ }^{68)}$. Furthermore, the level of oxidized LDL correlates positively with the expression of toll-like receptor 2 and interferon regulatory factor 1 , suggesting a relationship between oxidative stress and inflammation in the process of atherosclerotic plaque formation ${ }^{69)}$.

\section{Fatty Liver}

Non-alcoholic fatty liver disease (NAFLD) is characterized by the accumulation of intrahepatic triglycerides unrelated to alcohol consumption. NAFLD is often considered to be the hepatic manifestation of insulin resistance. The number of individuals with NAFLD in Western countries is increasing, and the condition has become the most common cause of chronic liver disease ${ }^{70)}$. In the large cohorts, subjects with NAFLD have been found to have an increased risk of developing metabolic syndrome and $\mathrm{T} 2 \mathrm{DM}^{71,72)}$. NAFLD includes a spectrum of disturbances encompassing various degrees of liver damage, ranging from simple lipid accumulation to non-alcoholic steatohepatitis (NASH), which is characterized by the presence of hepatocellular inflammation in association with fibrosis. NAFLD may progress to NASH and is a risk factor for the development of $\mathrm{CVD}^{73-75)}$ as well as hepatocellular carcinoma ${ }^{76)}$.

Oxidative stress plays a major role in the onset of NAFLD (Fig. 3 $)^{23)}$. Altered reduction/oxidation reactions generate ROS, thus leading to damage of hepatocytes. Very long and long chain fatty acids (VLCFAs and LCFAs) are oxidized by peroxisomes and metabolized as a result of microsomal oxidation. After the VLCFAs and LCFAs chains are shortened by peroxisomal and microsomal oxidation, they are oxidized in the mitochondrial oxidation system. Under conditions of insulin resistance, an increased amount of FFAs is released from adipose tissue and taken up by the liver. This overflow of FFAs increases ROS production as well as decreases the activity of antioxidant systems, thereby inducing oxidative stress ${ }^{77)}$. Mitochondria are responsible for oxidative phosphorylation and fatty acid beta-oxidation. These organelles are, in turn, the major source of ROS and are susceptible to oxidative damage. The excessive generation of ROS itself may be considered a direct effect of mitochondrial dysfunction $^{78)}$, which acts synergistically with inflammation in the generation of ROS, subsequently encouraging the progression from simple steatosis to $\mathrm{NASH}^{79}$. ROS also induce the secretion of cytokines, such as TNF $\alpha$, IL8 and transforming growth factor- $\beta$ (TGF $\beta$ ), all of which play a role in the development of steatohepatitis and fibrosis ${ }^{70)}$. 


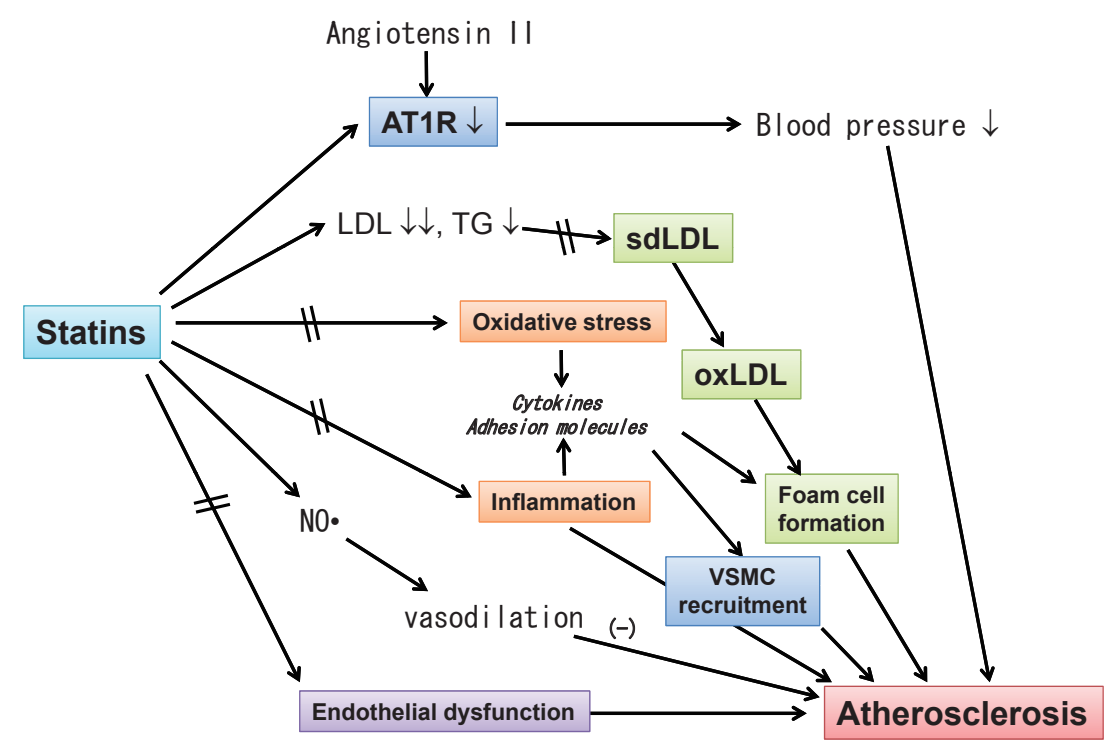

Fig. 4. Beneficial effects of statins in preventing the development of atherosclerosis

Statins inhibit the expression of angiotensin II type I receptor (AT1R), which subsequently reduces the production of oxygen-derived free radicals and decreases blood pressure. Statins reduce the production of proinflammatory proteins, such as chemokines and cytokines, and mitigate oxidative stress. They also inhibit the production of oxygenderived free radicals by reducing the low-density lipoprotein (LDL)-cholesterol level, increasing nitrous oxide (NO) synthesis and promoting antioxidant activities. Statins improve NO bioactivity by inhibiting the actions of NF- $\kappa \mathrm{B}$ and decreasing inflammatory protein production, both of which further contribute to preventing the onset and progression of atherosclerosis.

Triglycerides derived from circulating FFAs accumulate in the liver, which may lead to the onset of inflammation mediated by CD36. CD36 and its receptor play an important role in facilitating fatty acid uptake, which precedes the secretion and storage of triglycerides ${ }^{80,81)}$. CD36 is also involved in the inflammatory response in both adipocytes and macrophages associated with complications of diet-induced obesity $^{82)}$. Furthermore, insulin resistance plays an important role in the relationship between triglyceride accumulation and inflammation ${ }^{83,84)}$, as triglyceride accumulation in the liver aggravates hepatic insulin resistance, which subsequently induces low-grade inflammation ${ }^{85)}$. This series of events ultimately contributes to the development of steatohepatitis (Fig.3).

Taken together, the pathogenesis of NAFLD is not yet fully understood; however, accumulated data suggest that oxidative stress and an altered redox balance play critical roles in the onset of NAFLD and its progression from steatosis to steatohepatitis.

\section{Role of Statins in the Redox System from a Cardiovascular and Metabolic Perspective}

Statin therapy decreases cholesterol synthesis by inhibiting 3-hydroxy-3-methylglutaryl CoA reductase, which subsequently increases the activity of the LDL receptor and decreases the concentration of LDL-cholesterol in the plasma. In many large trials, treatment with statins has been shown to decrease cardiovascular morbidity and mortality by reducing $\mathrm{LDL}^{86-90)}$. In addition to their LDL-lowering actions, statins possess antioxidant and anti-inflammatory properties that may contribute to their cardioprotective effects ${ }^{91-93)}$. Therefore, it is important to consider the role played by the pleiotropic effects of statins in the management of cardiovascular and metabolic disorders. The various beneficial effects of statins are shown in Fig. 4.

\section{Role of the Antioxidant and Anti-Inflamma- tory Effects of Statins in Treating CVD}

A number of studies have demonstrated that statins directly inhibit LDL-cholesterol oxidation. In addition, LDL-cholesterol isolated from patients 
treated with simvastatin has been found to be protective against LDL oxidation ${ }^{94)}$, while fluvastatin inhibits LDL oxidation ${ }^{95)}$ and preferentially scavenges radicals directly ${ }^{96)}$. Interestingly, a direct comparison between fluvastatin and pravastatin found that fluvastatin exhibits much greater inhibition of LDL oxidation than pravastatin ${ }^{96}$. This reduction in lipid peroxidation may contribute to the ability of statins to prevent or reduce atherosclerosis ${ }^{97)}$.

Nitric oxide (NO), the smallest signaling molecule, is produced by NO synthase and controls vascular tone ${ }^{98)}$. The upregulation of $\mathrm{NO}$ formation without increases in superoxide production induced by statin treatment contributes to the inhibition of lipid peroxidation. In addition to its role as a potent endogenous vasodilator ${ }^{99)}$, $\mathrm{NO}$ possesses anti-inflammatory and antioxidant activities ${ }^{100}$ by inhibiting the release of proinflammatory cytokines ${ }^{101)}$ and the expression of endothelial cell adhesion molecules ${ }^{102)}$. $\mathrm{NO}$ is catalyzed by a family of NOS enzymes ${ }^{103)}$, and statins have been shown in both human studies and animal models to upregulate the NOS-3 expression ${ }^{104)}$ in a process that improves the endothelial function ${ }^{105,106)}$. In studies designed to determine the mechanism of eNOS upregulation induced by statins, mevastatin has been shown to significantly increase the levels of both eNOS mRNA and proteins in human endothelial cells ${ }^{107)}$. In addition, simvastatin and atorvastatin enhance the eNOS activity by activating the phosphatidylinositol 3-kinase/Akt pathway and decreasing caveolin abundance, respectively ${ }^{108,}{ }^{109)}$, and atorvastatin has been reported to reduce the infarct size by increasing the activity of iNOS ${ }^{110)}$. Hence, statins have the potential to enhance NO bioavailability in the vasculature by decreasing superoxide production and subsequent $\mathrm{NO}$ breakdown as well as upregulating NOS.

In addition, atorvastatin has been reported to inhibit platelet-mediated LDL oxidation and isoprostane formation ${ }^{111)}$. A recent study also demonstrated that atorvastatin therapy acutely reduces oxidative stress by inhibiting Nox2 in platelets ${ }^{112}$, while pitavastatin has been reported to mitigate oxidative stress and reduce elevated levels of ROS and NADPH oxidase in high-risk animal models ${ }^{113,114)}$. Furthermore, statins decrease the mRNA expression of NADPH oxidase subunits ${ }^{11)}$. These data suggest that statins exert antioxidant effects by modulating the NADPH-oxidase enzyme activity.

Statins are also involved in the isoprenylation pathway. The cardioprotective effects of statins may be related to the reduced synthesis of mevalonate, the immediate product of HMG-CoA reductase, rather than that of cholesterol itself. Moreover, statins inhibit the translocation of Rac-1, which is required for the production of NADPH oxidase, to the membrane ${ }^{11,115)}$. These effects of statins serve to reduce the oxidative stress burden on the vasculature.

Atorvastatin and lovastatin increase the production of catalase in the liver and aortic vascular smooth muscle cells ${ }^{11,116)}$. Rosuvastatin is known to have antioxidant properties due to its upregulation of glutathione synthesis ${ }^{117)}$. In addition, one study showed that pitavastatin directly inhibits the formation of ROS in endothelial cells ${ }^{118)}$. Therefore, individual statins exert distinct antioxidant effects via diverse mechanisms and/or their actions in various cell systems.

Statins have a number of anti-inflammatory effects $^{5,119)}$. For example, they reduce the level of C-reactive protein, a marker of inflammation and an independent predictor of $\mathrm{CVD}^{4,120)}$. Meanwhile, atorvastatin inhibits both proinflammatory cytokine release and monocyte adhesion in response to very low levels of endotoxin ${ }^{121)}$. In general, statin treatment reduces $\mathrm{NF}-\kappa \mathrm{B}$ activation ${ }^{122)}$, inhibits the CD40CD40 ligand expression ${ }^{38,123)}$ and decreases the matrix metalloproteinase levels in THP-1 monocytes ${ }^{124)}$ and human carotid plaques ${ }^{125)}$, while treatment with rosuvastatin, atorvastatin and/or simvastatin increases the HDL-cholesterol level ${ }^{126)}$, which has both antioxidant and anti-inflammatory properties. These HDL-raising effects of statins may also relieve oxidative stress.

\section{Effects of Statins on Fatty Liver}

Although the effects of statins on the pathogenesis of NAFLD has not yet been clarified, many studies have demonstrated the beneficial role of statins in treating NAFLD. In a study with a small number of patients, a significant reduction of hepatic steatosis was noted among the subjects taking statins compared to that observed in those not taking statins ${ }^{127)}$. Furthermore, studies of various statins have demonstrated reductions in the levels of aminotransferases and hepatic lipids ${ }^{128-130)}$. However, one small pilot study comparing simvastatin monotherapy with non-statin treatment found no significant reductions in the aminotransferase levels, degree of hepatic steatosis, inflammatory activity or fibrosis, despite a $26 \%$ reduction in the LDL level associated with statin use ${ }^{131)}$. In contrast, rosuvastatin and pitavastatin treatment has been shown to improve metabolic parameters and liver histology in patients with fatty liver and dyslipidemia ${ }^{132,133)}$. Of note, most of these trials were limited by a small sample size, their study design and the lack of control of confounding factors, such as lifestyle factors and the effects of concomitant drugs.

A limited number of studies have suggested pos- 
sible mechanisms by which statins improve NAFLD and/or reduce the aminotransferase activity. For example, simvastatin inhibits the proliferation of hepatic stellate cells and decreases the expression of collagen I, III and IV ${ }^{134)}$. This drug also improves the prognosis of hepatic fibrosis by increasing the eNOS expression and decreasing the iNOS expression in an animal model of fatty liver ${ }^{135)}$. Because oxidative stress is one of the main causative factors underlying the pathogenesis of NAFLD ${ }^{23)}$, statins appear to play a protective role against the progression of NAFLD via their antioxidant properties.

Statins are also effective in reducing the levels of biomarkers, such as TNF $\alpha$, IL6 and C-reactive protein, which are indicative of an advanced histology of $\mathrm{NASH}^{136)}$. Atorvastatin improves the disease activity via its TNF $\alpha$-lowering effects in biopsy-proven NASH patients ${ }^{137)}$, and rosuvastatin significantly ameliorates hepatic lobular inflammation by decreasing the hepatic mRNA expression of TNF $\alpha$ and IL6 ${ }^{138)}$.

Some statins increase the adiponectin level, which may decrease FFA delivery to the liver and thus slow the progression of steatosis ${ }^{128,139)}$. A recent study demonstrated that atorvastatin therapy prevents dietinduced lipid accumulation in the liver in guinea pigs via the downregulation of hepatic CD36 proteins, which subsequently facilitates the hepatic uptake of lipids ${ }^{140)}$. In a diet-induced fatty liver animal model, rosuvastatin was found to ameliorate hepatic fibrosis in association with a decrease in the hepatic mRNA expression of TGF- $\beta$, connective tissue growth factor and type-1 procollagen ${ }^{138)}$

Therefore, both in vitro and in vivo studies suggest that statins play a protective role in the development and progression of NAFLD via various mechanisms. However, further mechanistic studies are warranted to clarify the exact roles of statins in this field.

\section{Association between Statin Treatment and the Progression of Insulin Resistance and T2DM}

Although statins have been proven to be effective in reducing CVD, conflicting data exist regarding the effects of some statins on the risk of incident $\mathrm{T}_{2} \mathrm{DM}^{91,141,142)}$. Interestingly, a meta-analysis of randomized controlled trials suggested potential differences between individual statins, with pravastatin showing a trend toward reducing metabolic risks and atorvastatin, rosuvastatin and simvastatin together being associated with a significantly increased risk of T2DM vs. a placebo ${ }^{89)}$. More recent analyses have demonstrated an increased incidence of diabetes following statin treatment, regardless of the statin type ${ }^{91,142)}$.
High doses of statins reduce the risk of cardiovascular events, although they also tend to increase the risk of T2DM ${ }^{91)}$.

The mechanisms by which statins increase the risk of T2DM have not been fully elucidated. However, statins may decrease the production of metabolites of HMG-CoA, such as isoprenoids, which upregulate insulin-responsive glucose transporter (GLUT)4 , thereby enhancing glucose uptake ${ }^{143}$. Lovastatin, atorvastatin and simvastatin decrease isoprenoid synthesis and downregulate GLUT-4 production, thus inducing a reduction in insulin sensitivity ${ }^{92,143,144)}$.

\section{Effects of Individual Statins on the Adiponectin Levels}

Adiponectin, an insulin sensitizing adipocytokine linked to the redox system, may have an effect on the statin-adiponectin-insulin resistance relationship. For example, treatment with the globular domain of human adiponectin suppresses glucose-induced ROS in a dose-dependent manner up to $81 \%^{145)}$. In an in vitro study, treatment of endothelial cells with human adiponectin inhibited the release of oxidized LDLinduced superoxide, indicating that adiponectin suppresses cellular superoxide generation, possibly via an $\mathrm{NAD}(\mathrm{P}) \mathrm{H}$ oxidase-linked mechanism ${ }^{146)}$.

Individual statins may have different effects on the circulating and/or expression levels of adiponectin. Statins that increase adiponectin may have beneficial metabolic effects, such as improvements in the vascular actions of insulin, decreases in inflammation and reductions in endothelin-1 secretion in the endothelium. For example, pravastatin and pitavastatin both improve insulin sensitivity by increasing the circulating adiponectin levels in humans ${ }^{147,}{ }^{148}$. In contrast, other statins, particularly when administered at high doses, result in unfavorable effects, such as reductions in insulin secretion and the exacerbation of insulin resistance ${ }^{143)}$. For example, in one study, the blood glucose levels, as determined on oral glucose tolerance tests, were higher in the group treated with atorvastatin for six weeks than in the control group ${ }^{144)}$. In another study, simvastatin $(20 \mathrm{mg})$ treatment significantly decreased the plasma adiponectin levels and insulin sensitivity, while pravastatin $(40 \mathrm{mg})$ treatment significantly increased the plasma adiponectin levels and insulin sensitivity at equal lipid-lowering doses ${ }^{148)}$. In contrast, neutral effects of pitavastatin on glucose homeostasis were observed in two cohorts of subjects with metabolic syndrome, independent of the efficacy of this drug in reducing LDL ${ }^{149)}$. Most recently, the J-PREDICT study showed that pitavastatin treatment reduces the incidence of T2DM in Japanese subjects 
with prediabetes by $18 \%$ over three years (Odawara M, Pitavastatin and incident T2DM; $5^{\text {th }}$ Scientific Meeting of the Asian Association for the Study of Diabetes, 2013, Seoul, Korea). Therefore, differences in the metabolic actions of individual statins may be mediated by adiponectin, which is implicated in ROS production and oxidative stress. Therefore, the risk of inducing insulin resistance and benefits in reducing cardiovascular risks should be considered in an integrated fashion ${ }^{7,150)}$.

\section{Conclusions}

The worldwide obesity epidemic is driving enormous increases in the incidence of cardiometabolic disorders. Along with insulin resistance, atherogenic dyslipidemia, endothelial dysfunction, activation of the renin-angiotensin system, endoplasmic reticulum stress and dysregulation of the redox system with resulting low-grade inflammation appear to play a role in the development of cardiometabolic disorders. There is now compelling evidence that statins have the ability to prevent dysregulation of the redox system by reducing the oxidative stress that contributes to these conditions. Therefore, further studies focusing on the effects of statins beyond their LDL-lowering actions are clearly warranted.

\section{Funding Sources}

This study was supported by Seoul National University Bundang Hospital (B-1405/250-005).

\section{Disclosures}

Dr. Barter has received honoraria and/or research funding from Astra Zeneca, Kowa, MSD, Pfizer, Roche, Amgen, Novartis, Sanofi-Regeneron and CSL Behring. The other author declares that he has no relevant financial interests.

\section{References}

1) Baigent C, Blackwell L, Emberson J, Holland LE, Reith C, Bhala N, Peto R, Barnes EH, Keech A, Simes J, Collins R: Efficacy and safety of more intensive lowering of LDL cholesterol: a meta-analysis of data from 170,000 participants in 26 randomised trials. Lancet, 2010; 376: 1670-1681

2) Ford I, Murray H, Packard CJ, Shepherd J, Macfarlane PW, Cobbe SM: Long-term follow-up of the West of Scotland Coronary Prevention Study. N Engl J Med, 2007; 357: 1477-1486

3) Colhoun HM, Betteridge DJ, Durrington PN, Hitman
GA, Neil HA, Livingstone SJ, Thomason MJ, Mackness MI, Charlton-Menys V, Fuller JH: Primary prevention of cardiovascular disease with atorvastatin in type 2 diabetes in the Collaborative Atorvastatin Diabetes Study (CARDS): multicentre randomised placebo-controlled trial. Lancet, 2004; 364: 685-696

4) Jialal I, Stein D, Balis D, Grundy SM, ms-Huet B, Devaraj S: Effect of hydroxymethyl glutaryl coenzyme a reductase inhibitor therapy on high sensitive C-reactive protein levels. Circulation, 2001; 103: 1933-1935

5) Sparrow CP, Burton CA, Hernandez M, Mundt S, Hassing $\mathrm{H}$, Patel S, Rosa R, Hermanowski-Vosatka A, Wang PR, Zhang D, Peterson L, Detmers PA, Chao YS, Wright SD: Simvastatin has anti-inflammatory and antiatherosclerotic activities independent of plasma cholesterol lowering. Arterioscler Thromb Vasc Biol, 2001; 21: $115-121$

6) Stoll LL, McCormick ML, Denning GM, Weintraub NL: Antioxidant effects of statins. Drugs Today (Barc), 2004; 40: 975-990

7) Lim S, Sakuma I, Quon MJ, Koh KK: Differential metabolic actions of specific statins: clinical and therapeutic considerations. Antioxid Redox Signal, 2014; 20: 12861299

8) Stone NJ, Robinson J, Lichtenstein AH, Merz CN, Blum CB, Eckel RH, Goldberg AC, Gordon D, Levy D, Lloyd-Jones DM, McBride P, Schwartz JS, Shero ST, Smith SC, Jr., Watson K, Wilson PW: 2013 ACC/AHA Guideline on the Treatment of Blood Cholesterol to Reduce Atherosclerotic Cardiovascular Risk in Adults: A Report of the American College of Cardiology/American Heart Association Task Force on Practice Guidelines. Circulation, 2014; 129 (25 Suppl 2): S1-S45

9) Holvoet P: Relations between metabolic syndrome, oxidative stress and inflammation and cardiovascular disease. Verh K Acad Geneeskd Belg, 2008; 70: 193-219

10) Albertini R, Moratti R, De LG: Oxidation of low-density lipoprotein in atherosclerosis from basic biochemistry to clinical studies. Curr Mol Med, 2002; 2: 579-592

11) Wassmann S, Laufs U, Muller K, Konkol C, Ahlbory K, Baumer AT, Linz W, Bohm M, Nickenig G: Cellular antioxidant effects of atorvastatin in vitro and in vivo. Arterioscler Thromb Vasc Biol, 2002; 22: 300-305

12) Wagner AH, Kohler T, Ruckschloss U, Just I, Hecker M: Improvement of nitric oxide-dependent vasodilatation by HMG-CoA reductase inhibitors through attenuation of endothelial superoxide anion formation. Arterioscler Thromb Vasc Biol, 2000; 20: 61-69

13) Itabe $H$ : Oxidized low-density lipoproteins: what is understood and what remains to be clarified. Biol Pharm Bull, 2003; 26: 1-9

14) Steinberg D: The LDL modification hypothesis of atherogenesis: an update. J Lipid Res, 2009; 50 Suppl: S376-S381

15) Rosenson RS: Statins in atherosclerosis: lipid-lowering agents with antioxidant capabilities. Atherosclerosis, 2004; 173: 1-12

16) Del PA, Zaccagnino P, Di PM, Saltarella M, Oliveros CC, Nico B, Santoro G, Lorusso M: Role of mitochondria and reactive oxygen species in dendritic cell differ- 
entiation and functions. Free Radic Biol Med, 2008; 44: 1443-1451

17) Nicco C, Laurent A, Chereau C, Weill B, Batteux F: Differential modulation of normal and tumor cell proliferation by reactive oxygen species. Biomed Pharmacother, 2005; 59: 169-174

18) Wolf G: Role of reactive oxygen species in angiotensin II-mediated renal growth, differentiation, and apoptosis. Antioxid Redox Signal, 2005; 7: 1337-1345

19) Toledo-Pereyra LH, Lopez-Neblina F, Toledo AH: Reactive oxygen species and molecular biology of ischemia/ reperfusion. Ann Transplant, 2004; 9: 81-83

20) Colavitti R, Finkel T: Reactive oxygen species as mediators of cellular senescence. IUBMB Life, 2005; 57: 277 281

21) Delles C, Miller WH, Dominiczak AF: Targeting reactive oxygen species in hypertension. Antioxid Redox Signal, 2008; 10: 1061-1077

22) Patel RP, Moellering D, Murphy-Ullrich J, Jo H, Beckman JS, rley-Usmar VM: Cell signaling by reactive nitrogen and oxygen species in atherosclerosis. Free Radic Biol Med, 2000; 28: 1780-1794

23) Podrini C, Borghesan M, Greco A, Pazienza V, Mazzoccoli G, Vinciguerra M: Redox Homeostasis and Epigenetics in Non-alcoholic Fatty Liver Disease (NAFLD). Curr Pharm Des, 2013; 19: 2737-2746

24) Bagi Z, Feher A, Beleznai T: Preserved coronary arteriolar dilatation in patients with type 2 diabetes mellitus: implications for reactive oxygen species. Pharmacol Rep, 2009; 61: 99-104

25) Morel DW, DiCorleto PE, Chisolm GM: Endothelial and smooth muscle cells alter low density lipoprotein in vitro by free radical oxidation. Arteriosclerosis, 1984; 4: 357-364

26) Lamb DJ, Wilkins GM, Leake DS: The oxidative modification of low density lipoprotein by human lymphocytes. Atherosclerosis, 1992; 92: 187-192

27) Yoshida H, Kisugi R: Mechanisms of LDL oxidation. Clin Chim Acta, 2010; 411: 1875-1882

28) Nishi K, Itabe H, Uno M, Kitazato KT, Horiguchi H, Shinno K, Nagahiro S: Oxidized LDL in carotid plaques and plasma associates with plaque instability. Arterioscler Thromb Vasc Biol, 2002; 22: 1649-1654

29) Itabe H, Takano T: Oxidized low density lipoprotein: the occurrence and metabolism in circulation and in foam cells. J Atheroscler Thromb, 2000; 7: 123-131

30) Chen HW, Kuo CL, Huang CS, Kuo SJ, Liu CS: Oxidized low-density lipoproteins, autoantibodies against oxidized low-density lipoproteins and carotid intima media thickness in a clinically healthy population. Cardiology, 2008; 110: 252-259

31) Koenig W, Karakas M, Zierer A, Herder C, Baumert J, Meisinger C, Thorand B: Oxidized LDL and the risk of coronary heart disease: results from the MONICA/ KORA Augsburg Study. Clin Chem, 2011; 57: 11961200

32) Luoma JS, Kareinen A, Narvanen O, Viitanen L, Laakso M, Yla-Herttuala S: Autoantibodies against oxidized LDL are associated with severe chest pain attacks in patients with coronary heart disease. Free Radic Biol
Med, 2005; 39: 1660-1665

33) Itabe H, Takeshima E, Iwasaki H, Kimura J, Yoshida $Y$, Imanaka T, Takano T: A monoclonal antibody against oxidized lipoprotein recognizes foam cells in atherosclerotic lesions. Complex formation of oxidized phosphatidylcholines and polypeptides. J Biol Chem, 1994; 269: 15274-15279

34) de Boer OJ, van der Wal AC, Becker AE: Atherosclerosis, inflammation, and infection. J Pathol, 2000; 190: 237-243

35) Becker AE, de Boer OJ, van Der Wal AC: The role of inflammation and infection in coronary artery disease. Annu Rev Med, 2001; 52: 289-297

36) Biasucci LM, Cardillo MT: Biomarkers of inflammation and endothelial function: the holy grail of experimental and clinical medicine? Vascul Pharmacol, 2012; 56: 26-28

37) Madjid M, Willerson JT: Inflammatory markers in coronary heart disease. Br Med Bull, 2011; 100: 23-38

38) Cipollone F, Mezzetti A, Porreca E, Di FC, Nutini M, Fazia M, Falco A, Cuccurullo F, Davi G: Association between enhanced soluble CD40L and prothrombotic state in hypercholesterolemia: effects of statin therapy. Circulation, 2002; 106: 399-402

39) Galis ZS, Khatri JJ: Matrix metalloproteinases in vascular remodeling and atherogenesis: the good, the bad, and the ugly. Circ Res, 2002; 90: 251-262

40) Barnes PJ, Karin M: Nuclear factor-kappaB: a pivotal transcription factor in chronic inflammatory diseases. $\mathrm{N}$ Engl J Med, 1997; 336: 1066-1071

41) DeForge LE, Fantone JC, Kenney JS, Remick DG: Oxygen radical scavengers selectively inhibit interleukin 8 production in human whole blood. J Clin Invest, 1992; 90: 2123-2129

42) Sasaki S, Inoguchi T: The role of oxidative stress in the pathogenesis of diabetic vascular complications. Diabetes Metab J, 2012; 36: 255-261

43) Vamecq J, Dessein AF, Fontaine M, Briand G, Porchet N, Latruffe N, Andreolotti P, Cherkaoui-Malki M: Mitochondrial dysfunction and lipid homeostasis. Curr Drug Metab, 2012; 13: 1388-1400

44) Schrauwen P, Schrauwen-Hinderling V, Hoeks J, Hesselink MK: Mitochondrial dysfunction and lipotoxicity. Biochim Biophys Acta, 2010; 1801: 266-271

45) Calabrese V, Cornelius C, Leso V, Trovato-Salinaro A, Ventimiglia B, Cavallaro M, Scuto M, Rizza S, Zanoli L, Neri S, Castellino P: Oxidative stress, glutathione status, sirtuin and cellular stress response in type 2 diabetes. Biochim Biophys Acta, 2012; 1822: 729-736

46) Mokini Z, Chiarelli F: The molecular basis of diabetic microangiopathy. Pediatr Endocrinol Rev, 2006; 4: 138152

47) Sato T, Iwaki M, Shimogaito N, Wu X, Yamagishi S, Takeuchi M: TAGE (toxic AGEs) theory in diabetic complications. Curr Mol Med, 2006; 6: 351-358

48) Srivastava SK, Ramana KV, Bhatnagar A: Role of aldose reductase and oxidative damage in diabetes and the consequent potential for therapeutic options. Endocr Rev, 2005; 26: 380-392

49) Yan SF, Ramasamy R, Naka Y, Schmidt AM: Glycation, 
inflammation, and RAGE: a scaffold for the macrovascular complications of diabetes and beyond. Circ Res, 2003; 93: 1159-1169

50) Hammes HP, Du X, Edelstein D, Taguchi T, Matsumura T, Ju Q, Lin J, Bierhaus A, Nawroth P, Hannak D, Neumaier M, Bergfeld R, Giardino I, Brownlee M: Benfotiamine blocks three major pathways of hyperglycemic damage and prevents experimental diabetic retinopathy. Nat Med, 2003; 9: 294-299

51) Yamada K, Hara N, Shibata T, Osago H, Tsuchiya M: The simultaneous measurement of nicotinamide adenine dinucleotide and related compounds by liquid chromatography/electrospray ionization tandem mass spectrometry. Anal Biochem, 2006; 352: 282-285

52) Blinova K, Carroll S, Bose S, Smirnov AV, Harvey JJ, Knutson JR, Balaban RS: Distribution of mitochondrial $\mathrm{NADH}$ fluorescence lifetimes: steady-state kinetics of matrix NADH interactions. Biochemistry, 2005; 44: 2585-2594

53) Todisco S, Agrimi G, Castegna A, Palmieri F: Identification of the mitochondrial NAD + transporter in Saccharomyces cerevisiae. J Biol Chem, 2006; 281: 1524-1531

54) Ying W: NAD + /NADH and NADP + /NADPH in cellular functions and cell death: regulation and biological consequences. Antioxid Redox Signal, 2008; 10: 179206

55) Sugden MC, Holness MJ: Mechanisms underlying regulation of the expression and activities of the mammalian pyruvate dehydrogenase kinases. Arch Physiol Biochem, 2006; 112: 139-149

56) Blatnik M, Frizzell N, Thorpe SR, Baynes JW: Inactivation of glyceraldehyde-3-phosphate dehydrogenase by fumarate in diabetes: formation of S-(2-succinyl)cysteine, a novel chemical modification of protein and possible biomarker of mitochondrial stress. Diabetes, 2008; 57: 41-49

57) Codoner-Franch P, Navarro-Ruiz A, Fernandez-Ferri M, rilla-Codoner A, Ballester-Asensio E, Valls-Belles V: A matter of fat: insulin resistance and oxidative stress. Pediatr Diabetes, 2012; 13: 392-399

58) Sankhla M, Sharma TK, Mathur K, Rathor JS, Butolia V, Gadhok AK, Vardey SK, Sinha M, Kaushik GG: Relationship of oxidative stress with obesity and its role in obesity induced metabolic syndrome. Clin Lab, 2012; 58: 385-392

59) Brasil AR, Norton RC, Rossetti MB, Leao E, Mendes $\mathrm{RP}$ : C-reactive protein as an indicator of low intensity inflammation in children and adolescents with and without obesity. J Pediatr (Rio J ), 2007; 83: 477-480

60) Reyes M, Gahagan S, Diaz E, Blanco E, Leiva L, Lera L, Burrows R: Relationship of adiposity and insulin resistance mediated by inflammation in a group of overweight and obese Chilean adolescents. Nutr J, 2011; 10: 4

61): Executive Summary of The Third Report of The National Cholesterol Education Program (NCEP) Expert Panel on Detection, Evaluation, And Treatment of High Blood Cholesterol In Adults (Adult Treatment Panel III). JAMA, 2001; 285: 2486-2497

62) Yamagishi $S$, Matsuoka H, Kitano S, Hibi N, Jinnouchi
Y, Umei H, Iida S, Takenaka K, Matsui T, Nakamura K, Imaizumi T: Elevated circulating oxidized LDL levels in Japanese subjects with the metabolic syndrome. Int J Cardiol, 2007; 118: 270-272

63) Holvoet P, Lee DH, Steffes M, Gross M, Jacobs DR, Jr.: Association between circulating oxidized low-density lipoprotein and incidence of the metabolic syndrome. JAMA, 2008; 299: 2287-2293

64) Colas R, Sassolas A, Guichardant M, Cugnet-Anceau C, Moret M, Moulin P, Lagarde M, Calzada C: LDL from obese patients with the metabolic syndrome show increased lipid peroxidation and activate platelets. Diabetologia, 2011; 54: 2931-2940

65) Segers D, Helderman F, Cheng C, van Damme LC, Tempel D, Boersma E, Serruys PW, de CR, van der Steen AF, Holvoet P, Krams R: Gelatinolytic activity in atherosclerotic plaques is highly localized and is associated with both macrophages and smooth muscle cells in vivo. Circulation, 2007; 115: 609-616

66) Masella R, Vari R, D’Archivio M, Santangelo C, Scazzocchio B, Maggiorella MT, Sernicola L, Titti F, Sanchez M, Di MU, Leto G, Giovannini C: Oxidised LDL modulate adipogenesis in 3T3-L1 preadipocytes by affecting the balance between cell proliferation and differentiation. FEBS Lett, 2006; 580: 2421-2429

67) Podrez EA: Anti-oxidant properties of high-density lipoprotein and atherosclerosis. Clin Exp Pharmacol Physiol, 2010; 37: 719-725

68) Lu C, Gao Y, Zhou H, Tian H: The relationships between PON1 activity as well as oxLDL levels and coronary artery lesions in CHD patients with diabetes mellitus or impaired fasting glucose. Coron Artery Dis, 2008; 19: 565-573

69) Holvoet P, Davey PC, De KD, Doukoure M, Deridder E, Bochaton-Piallat ML, Gabbiani G, Beaufort E, Bishay K, Andrieux N, Benhabiles N, Marguerie G: Oxidized low-density lipoprotein correlates positively with toll-like receptor 2 and interferon regulatory factor-1 and inversely with superoxide dismutase- 1 expression: studies in hypercholesterolemic swine and THP-1 cells. Arterioscler Thromb Vasc Biol, 2006; 26: 15581565

70) Smith BW, Adams LA: Nonalcoholic fatty liver disease and diabetes mellitus: pathogenesis and treatment. Nat Rev Endocrinol, 2011; 7: 456-465

71) Adams LA, Waters OR, Knuiman MW, Elliott RR, Olynyk JK: NAFLD as a risk factor for the development of diabetes and the metabolic syndrome: an eleven-year follow-up study. Am J Gastroenterol, 2009; 104: 861867

72) Kasturiratne A, Weerasinghe S, Dassanayake AS, Rajindrajith S, de Silva AP, Kato N, Wickremasinghe AR, de Silva HJ: Influence of non-alcoholic fatty liver disease on the development of diabetes mellitus. J Gastroenterol Hepatol, 2013; 28: 142-147

73) Gariani K, Philippe J, Jornayvaz FR: Non-alcoholic fatty liver disease and insulin resistance: from bench to bedside. Diabetes Metab, 2013; 39: 16-26

74) Boddi M, Tarquini R, Chiostri M, Marra F, Valente S, Giglioli C, Gensini GF, Abbate R: Nonalcoholic fatty 
liver in nondiabetic patients with acute coronary syndromes. Eur J Clin Invest, 2013; 43: 429-438

75) Targher G, Arcaro G: Non-alcoholic fatty liver disease and increased risk of cardiovascular disease. Atherosclerosis, 2007; 191: 235-240

76) Starley BQ, Calcagno CJ, Harrison SA: Nonalcoholic fatty liver disease and hepatocellular carcinoma: a weighty connection. Hepatology, 2010; 51: 1820-1832

77) Ha HL, Yu DY: HBx-induced reactive oxygen species activates hepatocellular carcinogenesis via dysregulation of PTEN/Akt pathway. World J Gastroenterol, 2010; 16: $4932-4937$

78) Savu O, Sunkari VG, Botusan IR, Grunler J, Nikoshkov A, Catrina SB: Stability of mitochondrial DNA against reactive oxygen species (ROS) generated in diabetes. Diabetes Metab Res Rev, 2011; 27: 470-479

79) Begriche K, Igoudjil A, Pessayre D, Fromenty B: Mitochondrial dysfunction in NASH: causes, consequences and possible means to prevent it. Mitochondrion, 2006; 6: $1-28$

80) Koonen DP, Jacobs RL, Febbraio M, Young ME, Soltys CL, Ong H, Vance DE, Dyck JR: Increased hepatic CD36 expression contributes to dyslipidemia associated with diet-induced obesity. Diabetes, 2007; 56: 2863 2871

81) Chabowski A, Zendzian-Piotrowska M, Konstantynowicz K, Pankiewicz W, Miklosz A, Lukaszuk B, Gorski J: Fatty acid transporters involved in the palmitate and oleate induced insulin resistance in primary rat hepatocytes. Acta Physiol (Oxf), 2013; 207: 346-357

82) Cai L, Wang Z, Ji A, Meyer JM, van der Westhuyzen DR: Scavenger receptor CD36 expression contributes to adipose tissue inflammation and cell death in dietinduced obesity. PLoS One, 2012; 7: e36785

83) Kotronen A, Yki-Jarvinen H: Fatty liver: a novel component of the metabolic syndrome. Arterioscler Thromb Vasc Biol, 2008; 28: 27-38

84) Yki-Jarvinen $\mathrm{H}$ : Fat in the liver and insulin resistance. Ann Med, 2005; 37: 347-356

85) Rogowski O, Shapira I, Steinvil A, Berliner S: Low-grade inflammation in individuals with the hypertriglyceridemic waist phenotype: another feature of the atherogenic dysmetabolism. Metabolism, 2009; 58: 661-667

86) Sacks FM, Moye LA, Davis BR, Cole TG, Rouleau JL, Nash DT, Pfeffer MA, Braunwald E: Relationship between plasma LDL concentrations during treatment with pravastatin and recurrent coronary events in the Cholesterol and Recurrent Events trial. Circulation, 1998; 97: 1446-1452

87) LaRosa JC: Statins risk of coronary heart disease. JAMA, 2000; 283: 2935-2936

88) Manuel DG, Kwong K, Tanuseputro P, Lim J, Mustard CA, Anderson GM, Ardal S, Alter DA, Laupacis A: Effectiveness and efficiency of different guidelines on statin treatment for preventing deaths from coronary heart disease: modelling study. BMJ, 2006; 332: 1419

89) Coleman CI, Reinhart K, Kluger J, White CM: The effect of statins on the development of new-onset type 2 diabetes: a meta-analysis of randomized controlled trials. Curr Med Res Opin, 2008; 24: 1359-1362
90) Polisecki E, Muallem H, Maeda N, Peter I, Robertson M, McMahon AD, Ford I, Packard C, Shepherd J, Jukema JW, Westendorp RG, de Craen AJ, Buckley BM, Ordovas JM, Schaefer EJ: Genetic variation at the LDL receptor and HMG-CoA reductase gene loci, lipid levels, statin response, and cardiovascular disease incidence in PROSPER. Atherosclerosis, 2008; 200: 109-114

91) Preiss D, Seshasai SR, Welsh P, Murphy SA, Ho JE, Waters DD, DeMicco DA, Barter P, Cannon CP, Sabatine MS, Braunwald E, Kastelein JJ, de Lemos JA, Blazing MA, Pedersen TR, Tikkanen MJ, Sattar N, Ray KK: Risk of incident diabetes with intensive-dose compared with moderate-dose statin therapy: a meta-analysis. JAMA, 2011; 305: 2556-2564

92) Koh KK, Sakuma I, Quon MJ: Differential metabolic effects of distinct statins. Atherosclerosis, 2011;215: 1-8

93) Koh KK, Lim S, Sakuma I, Quon MJ: Caveats to aggressive lowering of lipids by specific statins. Int J Cardiol, 2012; 154: 97-101

94) Girona J, La Ville AE, Sola R, Plana N, Masana L: Simvastatin decreases aldehyde production derived from lipoprotein oxidation. Am J Cardiol, 1999; 83: 846-851

95) Yamamoto A, Ichihara K, Hoshi K: Antioxidative effect of fluvastatin, an inhibitor of 3-hydroxy-3-methylglutaryl coenzyme A reductase, on peroxidation of phospholipid liposomes. J Pharm Pharmacol, 2001; 53: 227-232

96) Rikitake $Y$, Kawashima $S$, Takeshita $S$, Yamashita $T$, Azumi H, Yasuhara M, Nishi H, Inoue N, Yokoyama M: Anti-oxidative properties of fluvastatin, an HMG-CoA reductase inhibitor, contribute to prevention of atherosclerosis in cholesterol-fed rabbits. Atherosclerosis, 2001; 154: 87-96

97) Karatzis E, Lekakis J, Papamichael C, Andreadou I, Cimponeriu A, Aznaouridis K, Papaioannou TG, Protogerou A, Mavrikakis M: Rapid effect of pravastatin on endothelial function and lipid peroxidation in unstable angina. Int J Cardiol, 2005; 101: 65-70

98) Rapoport RM, Draznin MB, Murad F: Endotheliumdependent relaxation in rat aorta may be mediated through cyclic GMP-dependent protein phosphorylation. Nature, 1983; 306: 174-176

99) Bredt DS, Snyder SH: Nitric oxide: a physiologic messenger molecule. Annu Rev Biochem, 1994; 63: 175195

100) Clancy RM, Abramson SB: Nitric oxide: a novel mediator of inflammation. Proc Soc Exp Biol Med, 1995; 210: 93-101

101) Thomassen MJ, Buhrow LT, Connors MJ, Kaneko FT, Erzurum SC, Kavuru MS: Nitric oxide inhibits inflammatory cytokine production by human alveolar macrophages. Am J Respir Cell Mol Biol, 1997; 17: 279-283

102) Hill JR, Corbett JA, Kwon G, Marshall CA, McDaniel ML: Nitric oxide regulates interleukin 1 bioactivity released from murine macrophages. J Biol Chem, 1996; 271: 22672-22678

103) Wang Y, Marsden PA: Nitric oxide synthases: gene structure and regulation. Adv Pharmacol, 1995; 34: 71-90

104) Wassmann S, Nickenig G: Interrelationship of free oxygen radicals and endothelial dysfunction--modulation by statins. Endothelium, 2003; 10: 23-33 
105) Marchesi S, Lupattelli G, Siepi D, Schillaci G, Vaudo G, Roscini AR, Sinzinger H, Mannarino E: Short-term atorvastatin treatment improves endothelial function in hypercholesterolemic women. J Cardiovasc Pharmacol, 2000; 36: 617-621

106) Wassmann S, Faul A, Hennen B, Scheller B, Bohm M, Nickenig G: Rapid effect of 3-hydroxy-3-methylglutaryl coenzyme a reductase inhibition on coronary endothelial function. Circ Res, 2003; 93: e98-e103

107) Laufs U, Liao JK: Post-transcriptional regulation of endothelial nitric oxide synthase mRNA stability by Rho GTPase. J Biol Chem, 1998; 273: 24266-24271

108) Kureishi Y, Luo Z, Shiojima I, Bialik A, Fulton D, Lefer DJ, Sessa WC, Walsh K: The HMG-CoA reductase inhibitor simvastatin activates the protein kinase Akt and promotes angiogenesis in normocholesterolemic animals. Nat Med, 2000; 6: 1004-1010

109) Feron O, Dessy C, Desager JP, Balligand JL: Hydroxymethylglutaryl-coenzyme A reductase inhibition promotes endothelial nitric oxide synthase activation through a decrease in caveolin abundance. Circulation, 2001; 103: 113-118

110) Atar S, Ye Y, Lin Y, Freeberg SY, Nishi SP, Rosanio S, Huang MH, Uretsky BF, Perez-Polo JR, Birnbaum Y: Atorvastatin-induced cardioprotection is mediated by increasing inducible nitric oxide synthase and consequent S-nitrosylation of cyclooxygenase-2. Am J Physiol Heart Circ Physiol, 2006; 290: H1960-H1968

111) Cangemi R, Loffredo L, Carnevale R, Perri L, Patrizi MP, Sanguigni V, Pignatelli P, Violi F: Early decrease of oxidative stress by atorvastatin in hypercholesterolaemic patients: effect on circulating vitamin E. Eur Heart J, 2008; 29: 54-62

112) Pignatelli P, Carnevale R, Pastori D, Cangemi R, Napoleone L, Bartimoccia S, Nocella C, Basili S, Violi F: Immediate antioxidant and antiplatelet effect of atorvastatin via inhibition of Nox2. Circulation, 2012; 126: 92-103

113) Umeji K, Umemoto $S$, Itoh $S$, Tanaka $M$, Kawahara $S$, Fukai T, Matsuzaki M: Comparative effects of pitavastatin and probucol on oxidative stress, $\mathrm{Cu} / \mathrm{Zn}$ superoxide dismutase, PPAR-gamma, and aortic stiffness in hypercholesterolemia. Am J Physiol Heart Circ Physiol, 2006; 291: H2522-H2532

114) Chinen I, Shimabukuro M, Yamakawa K, Higa N, Matsuzaki T, Noguchi K, Ueda S, Sakanashi M, Takasu N: Vascular lipotoxicity: endothelial dysfunction via fattyacid-induced reactive oxygen species overproduction in obese Zucker diabetic fatty rats. Endocrinology, 2007; 148: $160-165$

115) Wassmann S, Laufs U, Baumer AT, Muller K, Konkol C, Sauer H, Bohm M, Nickenig G: Inhibition of geranylgeranylation reduces angiotensin II-mediated free radical production in vascular smooth muscle cells: involvement of angiotensin AT1 receptor expression and Rac1 GTPase. Mol Pharmacol, 2001; 59: 646-654

116) Jeon SM, Bok SH, Jang MK, Lee MK, Nam KT, Park YB, Rhee SJ, Choi MS: Antioxidative activity of naringin and lovastatin in high cholesterol-fed rabbits. Life Sci, 2001; 69: 2855-2866
117) Schupp N, Schmid U, Heidland A, Stopper H: Rosuvastatin protects against oxidative stress and DNA damage in vitro via upregulation of glutathione synthesis. Atherosclerosis, 2008; 199: 278-287

118) Honjo T, Inoue N, Shiraki R, Kobayashi S, Otsui K, Takahashi M, Hirata K, Kawashima S, Yokozaki H, Yokoyama M: Endothelial urocortin has potent antioxidative properties and is upregulated by inflammatory cytokines and pitavastatin. J Vasc Res, 2006; 43: 131138

119) Kleemann R, Princen HM, Emeis JJ, Jukema JW, Fontijn RD, Horrevoets AJ, Kooistra T, Havekes LM: Rosuvastatin reduces atherosclerosis development beyond and independent of its plasma cholesterol-lowering effect in $\mathrm{APOE}^{*} 3$-Leiden transgenic mice: evidence for antiinflammatory effects of rosuvastatin. Circulation, 2003; 108: 1368-1374

120) Ridker PM, Buring JE, Cook NR, Rifai N: C-reactive protein, the metabolic syndrome, and risk of incident cardiovascular events: an 8-year follow-up of 14719 initially healthy American women. Circulation, 2003; 107: 391-397

121) Rice JB, Stoll LL, Li WG, Denning GM, Weydert J, Charipar E, Richenbacher WE, Miller FJ, Jr., Weintraub NL: Low-level endotoxin induces potent inflammatory activation of human blood vessels: inhibition by statins. Arterioscler Thromb Vasc Biol, 2003; 23: 1576-1582

122) Dichtl W, Dulak J, Frick M, Alber HF, Schwarzacher SP, Ares MP, Nilsson J, Pachinger O, Weidinger F: HMGCoA reductase inhibitors regulate inflammatory transcription factors in human endothelial and vascular smooth muscle cells. Arterioscler Thromb Vasc Biol, 2003; 23: 58-63

123) Schonbeck U, Gerdes N, Varo N, Reynolds RS, Horton DB, Bavendiek U, Robbie L, Ganz P, Kinlay S, Libby P: Oxidized low-density lipoprotein augments and 3-hydroxy-3-methylglutaryl coenzyme A reductase inhibitors limit CD40 and CD40L expression in human vascular cells. Circulation, 2002; 106: 2888-2893

124) Wong B, Lumma WC, Smith AM, Sisko JT, Wright SD, Cai TQ: Statins suppress THP-1 cell migration and secretion of matrix metalloproteinase 9 by inhibiting geranylgeranylation. J Leukoc Biol, 2001; 69: 959-962

125) Crisby M, Nordin-Fredriksson G, Shah PK, Yano J, Zhu J, Nilsson J: Pravastatin treatment increases collagen content and decreases lipid content, inflammation, metalloproteinases, and cell death in human carotid plaques: implications for plaque stabilization. Circulation, 2001; 103: 926-933

126) Barter PJ, Brandrup-Wognsen G, Palmer MK, Nicholls SJ: Effect of statins on HDL-C: a complex process unrelated to changes in LDL-C: analysis of the VOYAGER Database. J Lipid Res, 2010; 51: 1546-1553

127) Ekstedt M, Franzen LE, Mathiesen UL, Holmqvist M, Bodemar G, Kechagias S: Statins in non-alcoholic fatty liver disease and chronically elevated liver enzymes: a histopathological follow-up study. J Hepatol, 2007; 47: $135-141$

128) Hyogo H, Tazuma S, Arihiro K, Iwamoto K, Nabeshima Y, Inoue M, Ishitobi T, Nonaka M, Chayama K: Efficacy 
of atorvastatin for the treatment of nonalcoholic steatohepatitis with dyslipidemia. Metabolism, 2008; 57: 1711-1718

129) Abel T, Feher J, Dinya E, Eldin MG, Kovacs A: Safety and efficacy of combined ezetimibe/simvastatin treatment and simvastatin monotherapy in patients with non-alcoholic fatty liver disease. Med Sci Monit, 2009; 15: MS6-11

130) Antonopoulos S, Mikros S, Mylonopoulou M, Kokkoris S, Giannoulis G: Rosuvastatin as a novel treatment of non-alcoholic fatty liver disease in hyperlipidemic patients. Atherosclerosis, 2006; 184: 233-234

131) Nelson A, Torres DM, Morgan AE, Fincke C, Harrison SA: A pilot study using simvastatin in the treatment of nonalcoholic steatohepatitis: A randomized placebocontrolled trial. J Clin Gastroenterol, 2009; 43: 990-994

132) Nakahara T, Hyogo H, Kimura Y, Ishitobi T, Arihiro K, Aikata H, Takahashi S, Chayama K: Efficacy of rosuvastatin for the treatment of non-alcoholic steatohepatitis with dyslipidemia: An open-label, pilot study. Hepatol Res, 2012; 42: 1065-1072

133) Hyogo H, Ikegami T, Tokushige K, Hashimoto E, Inui K, Matsuzaki Y, Tokumo H, Hino F, Tazuma S: Efficacy of pitavastatin for the treatment of non-alcoholic steatohepatitis with dyslipidemia: An open-label, pilot study. Hepatol Res, 2011; 41: 1057-1065

134) Rombouts K, Kisanga E, Hellemans K, Wielant A, Schuppan D, Geerts A: Effect of HMG-CoA reductase inhibitors on proliferation and protein synthesis by rat hepatic stellate cells. J Hepatol, 2003; 38: 564-572

135) Wang W, Zhao C, Zhou J, Zhen Z, Wang Y, Shen C: Simvastatin ameliorates liver fibrosis via mediating nitric oxide synthase in rats with non-alcoholic steatohepatitisrelated liver fibrosis. PLoS One, 2013; 8: e76538

136) Argo CK, Loria P, Caldwell SH, Lonardo A: Statins in liver disease: a molehill, an iceberg, or neither? Hepatology, 2008; 48: 662-669

137) Hyogo H, Yamagishi S, Maeda S, Kimura Y, Ishitobi T, Chayama K: Atorvastatin improves disease activity of nonalcoholic steatohepatitis partly through its tumour necrosis factor-alpha-lowering property. Dig Liver Dis, 2012; 44: 492-496

138) Okada Y, Yamaguchi K, Nakajima T, Nishikawa T, Jo M, Mitsumoto Y, Kimura H, Nishimura T, Tochiki N, Yasui K, Mitsuyoshi H, Minami M, Kagawa K, Okanoue T, Itoh Y: Rosuvastatin ameliorates high-fat and high-cholesterol diet-induced nonalcoholic steatohepatitis in rats. Liver Int, 2013; 33: 301-311

139) Kimura Y, Hyogo H, Yamagishi S, Takeuchi M, Ishitobi T, Nabeshima Y, Arihiro K, Chayama K: Atorvastatin decreases serum levels of advanced glycation endproducts (AGEs) in nonalcoholic steatohepatitis (NASH) patients with dyslipidemia: clinical usefulness of AGEs as a biomarker for the attenuation of NASH. J Gastro- enterol, 2010; 45: 750-757

140) Podszun MC, Grebenstein N, Spruss A, Schlueter T, Kremoser C, Bergheim I, Frank J: Dietary alpha-tocopherol and atorvastatin reduce high-fat-induced lipid accumulation and down-regulate CD36 protein in the liver of guinea pigs. J Nutr Biochem, 2014; 25: 573-579

141) Ridker PM, Danielson E, Fonseca FA, Genest J, Gotto AM, Jr., Kastelein JJ, Koenig W, Libby P, Lorenzatti AJ, MacFadyen JG, Nordestgaard BG, Shepherd J, Willerson JT, Glynn RJ: Rosuvastatin to prevent vascular events in men and women with elevated C-reactive protein. N Engl J Med, 2008; 359: 2195-2207

142) Sattar N, Preiss D, Murray HM, Welsh P, Buckley BM, de Craen AJ, Seshasai SR, McMurray JJ, Freeman DJ, Jukema JW, Macfarlane PW, Packard CJ, Stott DJ, Westendorp RG, Shepherd J, Davis BR, Pressel SL, Marchioli R, Marfisi RM, Maggioni AP, Tavazzi L, Tognoni G, Kjekshus J, Pedersen TR, Cook TJ, Gotto AM, Clearfield MB, Downs JR, Nakamura H, Ohashi Y, Mizuno K, Ray KK, Ford I: Statins and risk of incident diabetes: a collaborative meta-analysis of randomised statin trials. Lancet, 2010; 375: 735-742

143) Chamberlain LH: Inhibition of isoprenoid biosynthesis causes insulin resistance in 3T3-L1 adipocytes. FEBS Lett, 2001; 507: 357-361

144) Kanda M, Satoh K, Ichihara K: Effects of atorvastatin and pravastatin on glucose tolerance in diabetic rats mildly induced by streptozotocin. Biol Pharm Bull, 2003; 26: 1681-1684

145) Chen H, Montagnani M, Funahashi T, Shimomura I, Quon MJ: Adiponectin stimulates production of nitric oxide in vascular endothelial cells. J Biol Chem, 2003; 278: 45021-45026

146) Motoshima H, Wu X, Mahadev K, Goldstein BJ: Adiponectin suppresses proliferation and superoxide generation and enhances eNOS activity in endothelial cells treated with oxidized LDL. Biochem Biophys Res Commun, 2004; 315: 264-271

147) Teramoto T, Shimano H, Yokote K, Urashima M: New evidence on pitavastatin: efficacy and safety in clinical studies. Expert Opin Pharmacother, 2010; 11: 817-828

148) Koh KK, Quon MJ, Han SH, Lee Y, Kim SJ, Park JB, Shin EK: Differential metabolic effects of pravastatin and simvastatin in hypercholesterolemic patients. Atherosclerosis, 2009; 204: 483-490

149) Chapman MJ, Orsoni A, Robillard P, Hounslow N, Sponseller CA, Giral P: Effect of high-dose pitavastatin on glucose homeostasis in patients at elevated risk of new-onset diabetes: insights from the CAPITAIN and PREVAIL-US studies. Curr Med Res Opin, 2014;

150) Lim S, Sakuma I, Quon MJ, Koh KK: Potentially important considerations in choosing specific statin treatments to reduce overall morbidity and mortality. Int J Cardiol, 2013; 167: 1696-1702 